\section{RESEARCH PAPER \\ Business regulation, inward foreign direct investment, and economic growth in the new European Union member states}

\author{
Matthew M.C. Allen \\ Comparative and International Business Research Centre, \\ Manchester Business School, The University of Manchester, Manchester, UK, and \\ Maria L. Aldred \\ Department of Management, \\ Manchester Metropolitan University Business School, Manchester, UK
}

\begin{abstract}
Purpose - The purpose of this paper is to assess the extent to which institutional convergence has taken place in the new European Union (EU) member states. It does so by contrasting arguments that are inspired by transaction-cost economics within the mainstream international-business literature and contentions within the comparative-capitalisms perspective. A corollary of arguments within the former is that those countries that have less transparent ways of doing business will post poorer economic growth records than those with more predictable and less costly regulations. By contrast, contentions within the comparative-capitalisms literature lead to expectations that a broader set of institutional factors will shape economic growth.

Design/methodology/approach - The article adopts a fuzzy-set qualitative comparative analysis approach to examine the necessary and sufficient causal conditions for economic growth in the region. Findings - There is a great deal of institutional diversity within the new EU member states in Central and Eastern Europe. There are no clusters of countries around a specific variety of capitalism or an economic model that has above-average economic growth rates and that is characterized by institutions that lower the costs of market transacting. This, in turn, suggests that convergence pressures are not as great as the mainstream international-business literature has argued.

Research limitations/implications - Future research could complement this study by adopting a cross-country, comparative micro- or firm-level approach to examine the ways in which different institutional factors, both individually and collectively, shape the growth of businesses and consequently, economies.

Originality/value - Mainstream international business tends to focus on regulation and market-supporting institutions to explain growth in developing economies. This research has shown that a broader view of institutions needs to be adopted, as some countries have been able to post strong economic growth figures despite institutional environments that do not lower the costs of market-based contracting.
\end{abstract}

Keywords European Union, Central and Eastern Europe, International business,

International investments, Comparative capitalisms, Business systems, Institutional voids,

Economic growth

Paper type Research paper

The authors would like to thank two anonymous reviewers for their very helpful comments and suggestions. The authors take responsibility for any errors that remain. 
CPOIB

9,3

302

\section{Introduction}

Within the mainstream international-business literature, the importance of locational differences has recently come to the fore in many studies (Dunning, 2009; Meyer et al., 2011; Mudambi and Navarra, 2002; Rugman et al., 2011). However, in contrast to studies that are underpinned by a more comparative sociological perspective, many of these analyses within the orthodox international-business literature adopt a relatively narrow definition of "institutions" when examining the consequences of any locational differences for economic activities. For instance, many studies focus on a relatively narrow range of formal, regulatory institutions that shape arm's length, market-based economic activities (Delios and Henisz, 2003; Khanna and Palepu, 1997, 2006, 2010; Khanna and Rivkin, 2001; Meyer et al., 2011; Tan and Meyer, 2010; Young et al., 2008).

These institutions are then used in some studies to explain either implicitly or explicitly the growth and competitiveness of economies or individual companies (Bevan et al., 2004; Khanna and Palepu, 2004, 2010; Meyer et al., 2011). Institutions that reduce the costs of running firms or using markets are viewed preferentially (Djankov et al., 2006; Henisz, 2000; Globerman and Shapiro, 2003). Consequently, those countries with institutions that support market-based transacting are expected to grow more quickly than those countries that do not have such institutions. A corollary of this is that institutional regimes will converge, if countries wish to grow. Put differently, those economies with institutions that are perceived to increase transaction costs will grow more slowly.

However, in studies that adopt a more sociological perspective that is common within the "comparative capitalisms" literature, convergence amongst institutional regimes towards one that reduces asymmetric information and promotes the market-based co-ordination of economic activities through contracting are not expected (Hall and Soskice, 2001; Whitley, 1999, 2007; Wood and Lane, 2012, p. 6). This, in part, reflects the fact that a broader definition of institutions is adopted in the comparative-capitalisms literature than is common in the international-business literature (Hotho and Pedersen, 2012; Jackson and Deeg, 2008). In short, institutions, in the shape of formal and informal rules, both constitute and regulate strategic actors (Whitley and Morgan, 2012). Within the former perspective, then, institutions do not just act as constraints on actors: they also shape their protean natures, interests, strategic priorities, and organizational capabilities (Boyer, 2011; Whitley, 1999, 2007). Consequently, companies within environments that are characterized by "missing" market-supporting institutions can be expected (to attempt) to create competitive competencies that are supported by their institutional context (Whitley, 2007; Khanna and Rivkin, 2001; Miller et al., 2009; Puffer et al., 2010). In contrast to the mainstream international-business literature, therefore, the comparative-capitalisms literature does not expect to see convergence amongst institutional regimes.

It is this issue of institutions, economic growth, and convergence that this article assesses. Drawing on country-level data, it analyses the extent to which there is any one set of institutions that is clearly associated with superior macro-economic performance. From the perspective of the international-business literature, institutions that promote forms of market contracting will consistently and primarily be associated with superior macro-economic performance. By contrast, the comparative-capitalism perspective leads to expectations that there are likely to be a number of clusters that lead to good macro-economic performance. Whilst institutions associated with 
"unhindered" markets can be expected to lead to growth within the New EU member comparative-capitalisms framework, other factors that, from a mainstream international-business perspective, will impede market-based activities may be associated with higher GDP growth rates, too (Hall and Soskice, 2001; Streeck, 1997; Whitley, 1999, 2007).

Central and Eastern Europe (CEE) provides an ideal location to examine the extent to which convergence around a common institutional model is likely. The reasons for this are threefold. First, the new member states of the European Union (EU) in the region are highly dependent upon inward foreign direct investment (FDI) (Bohle and Greskovits, 2006; Nölke and Vliegenthart, 2009). Second and consequently, the competition between the new member states for such investment has led to pressures to create institutional frameworks that foreign firms find most attractive (Hansmann and Kraakman, 2001; Lane, 2007; McCahery et al., 2004). Finally, the collapse of communism in the region created an opportunity to implement changes at a time when restrictions on the extent to which change could occur were reduced (Vaughan-Whitehead, 2003).

The next section sets out the theoretical differences between the two perspectives examined here. This is followed by sections on the research design; data, method, and variable calibration; and results. This paper concludes with a discussion of the results that draws out some of the study's implications for future research.

\section{Theoretical background}

Within the international-business literature, the dominant approach to institutions privileges formal regulations that impact upon arm's length, market-based activities (Hotho and Pedersen, 2012; Jackson and Deeg, 2008). In other words, the orthodox international-business literature focuses primarily on institutions as market-promoting rules and regulations (Delios and Henisz, 2003; Globerman and Shapiro, 2003; Khanna and Palepu, 2004; Peng et al., 2008; Meyer, 2001; Mudambi and Navarra, 2002, p. 639). Consequently, analyses within the international-business literature have, for instance, sought to explain the volume of inward FDI in, and the most appropriate entry mode into, foreign markets marked by "weak" institutions (Bevan et al., 2004; Brouthers, 2002; Delios and Henisz, 2003; Meyer, 2001). Prominent studies have also examined the degree of horizontal and vertical integration, which can help to overcome market deficiencies, of firms in such institutional environments (Cuervo-Cazurra and Genc, 2008; Khanna and Palepu, 1999, 2000; Khanna and Rivkin, 2001; Miller et al., 2009; Peng et al., 2005; Puffer et al., 2010). Indeed, the term "institutional void" is used in some of these studies to denote the complete or partial absence of market-supporting institutions (Khanna and Rivkin, 2001; Khanna and Palepu, 1997, 1999, 2010), such as poorly enforced regulations and capricious legal decisions.

In this international-business perspective, then, vertical and horizontal ownership control or managers' personal networks are regarded as substitutes for a relatively narrow set of "inadequate" market-related institutions (Jackson and Deeg, 2008). Such institutions are, generally, not assessed in terms of their influence over the firm's capabilities and, hence, competitiveness; rather, the role of institutions in the emerging economies that are examined is primarily, but not exclusively, to increase the transaction costs associated with market contracting (Chakrabarty, 2009; Djankov 
CPOIB 9,3 et al., 2006; Hotho and Pedersen, 2012, p. 242; Khanna and Palepu, 1999, 2000, 2010; Peng et al., 2008; Miller et al., 2009; Mudambi and Navarra, 2002).

This view of institutions underpins several prominent studies within the international-business literature that seek to explain either implicitly or explicitly the growth and competitiveness of economies or individual companies (Bevan et al., 2004; Henisz, 2000; Globerman and Shapiro, 2003; Khanna and Palepu, 2004; Meyer et al., 2011). Transaction cost-reducing institutions are seen as being beneficial to economic outcomes (Bevan et al., 2004; Djankov et al., 2006; Henisz, 2000; Globerman and Shapiro, 2003). Consequently, those countries with institutions that facilitate market transactions are, implicitly or explicitly, expected to grow more quickly than those countries that do not have such institutions. Thus, institutional regimes can be expected to converge around a common model that reduces the costs associated with market transacting if economies wish to grow.

This expectation does not underpin the comparative-capitalisms literature. The reasons for this are fourfold. First, within the comparative-capitalisms literature, institutions do not just act as the "rules of the game" that shape actors' behaviour: they also constitute actors. This means that firms should be viewed as separately constituted collective actors that have varying degrees of autonomy (Allen et al., 2007; Crouch, 2005; Whitley, 2006). Consequently, firms in different institutional settings should not be construed as being homogeneous. Their strategic priorities, thus, vary. So, too, do their institutional preferences. Institutional convergence will not, consequently, be expected to occur.

Second, within the comparative-capitalisms literature the possibility that institutions can act not just as hindrances, but as "beneficial constraints" (Streeck, 1997; Djankov et al., 2006, p. 396) is incorporated into analyses. For instance, the presence of relatively strict employment laws that make it difficult for employers to lay-off workers may be viewed by companies as "beneficial constraints" that encourage firms to invest in the skills of their workers to a greater extent than might otherwise be the case (Harcourt and Wood, 2007). Thus, firms can respond to institutions or their (partial) absence in different ways. Within the comparative-capitalisms literature, then, institutions do not only help to reduce transaction costs. The comparative-capitalisms literature offers a richer, more nuanced perspective on institutions compared to much of the transaction cost-inspired international-business literature.

Third and relatedly, institutions are analysed not just in terms of the ways in which they constitute actors, but also in regards to their impact on firms' competitive competencies (Allen et al., 2006, 2011; Becker-Ritterspach et al., 2010; Hall and Soskice, 2001; Miozzo and Yamin, 2012; Whitley, 1999, 2007). Such competencies can be expected to vary between firms that are based in different institutional settings. There is not, consequently, the expectation that institutional regimes will converge towards one that privileges market-based transactions (Wood and Lane, 2012). Within institutional frameworks in which personal ties are often the only reliable means to promote predictable behaviour and in which the legal system is either too costly to use or too erratic in its decisions, firms are likely to develop capabilities based on those close personal networks As a result, decision-making powers and discretion will not be extended to those employees who do not have close ties to the owner-managers (Whitley, 2007, p. 18). This will restrict organizational learning (Whitley, 2007). 
However, within the comparative-capitalisms literature, the term "institutional void" would not be used to categorize such a situation. This may be because the term implicitly privileges certain, transaction cost-reducing institutional settings over others.

To be sure, there are studies within the broad international-business literature that examine the ways in which firms respond to institutional environments that do not, in general, support market-based activities (Estrin and Prevezer, 2011; Khanna and Rivkin, 2001; Miller et al., 2009; Puffer et al., 2010); however, the focus remains on the ways in which activities are integrated within firms or business groups rather than co-ordinated in markets in order to reduce transaction costs. The analysis does not provide a detailed assessment of the ways in which the capabilities that underpin companies' competitive advantages are created and developed.

Finally, an important theme within the comparative-capitalism literature, and one that further differentiates it from much of the international-business literature, is "institutional complementarity" (Crouch, 2005; Crouch et al., 2005; Hall and Soskice, 2001; Hotho and Pedersen, 2012; Pajunen, 2008). Although there has been much discussion over the meaning of this term, it can be defined here to mean that the presence of one institution increases the efficiency of another. This highlights the ways in which individual institutions may interact with one another to reinforce pressures on senior managers and others within firms to take particular decisions. For example, employment regulations that require companies to adopt a long-term perspective with regard to their employees can be complemented by a financial system that is characterized by long-term funding. In such an institutional environment, companies compared to those in settings in which institutional investors play a prominent role and in which hiring and firing is relatively easy - are likely to find it easier to pursue strategies that require a focus on medium- to long-term growth at the potential expense of increases in short-term profitability. This, in turn, is likely to lead to firm success in those sectors of the economy that require a longer-term approach to investments and employees (Casper and Whitley, 2004; Hall and Soskice, 2001).

What is lacking from the international-business literature, therefore, is a comparative analysis of the ways in which institutions, both singly and collectively, form firms, shape firms' competitive advantages across countries and, hence, influence GDP rates. To be sure, studies that assess the influence on macro-economic outcomes, such as unemployment and relative wages, of important institutions do exist (Botero et al., 2004; Djankov et al., 2006; Henisz, 2000). However, these focus on a relatively narrow range of institutions, be they legal traditions, business regulations or political hazards (for a related critique, see Wood and Lane, 2012; Khanna and Palepu, 2010). They do not take into consideration either a broad range of institutions or their interactive influences. By doing so, they offer a highly parsimonious view of economic growth and a "narrow" approach to institutions. This, in turn, indicates that, within the international-business literature, a largely implicit assumption is that countries should adopt more transparent and predictable institutional regimes if they wish to promote economic growth.

\section{Research design}

This article examines the pressures for convergence by assessing the links between a broad range of institutions and GDP growth rates in CEE. If it can be shown that

\section{New EU member states}

305 
CPOIB

9,3

306 higher GDP growth rates are consistently and primarily associated with institutions that facilitate activities contracted through the market, this would indicate that countries in the region need to adopt a relatively standard set of measures if they wish to grow. Indeed, for international-business scholars, the main expectation is that narrow, market-promoting institutions are likely to be the primary influence behind higher GDP growth rates in CEE. For comparative-capitalisms scholars, there is an expectation of greater diversity between countries as well as the anticipation that a number of institutions will shape GDP growth rates in the region (Hall and Soskice, 2001; Wood and Lane, 2012).

The analysis uses fuzzy-set qualitative comparative analysis (fsQCA) (Ragin, 2000, 2006, 2008a) that is increasingly being used in related studies to identify the complex institutional configurations of both sufficient and necessary causes of various outcomes (Allen and Aldred, 2011; Boyer, 2004; Jackson, 2005; Pajunen, 2008; Schneider et al., 2010). The use of fuzzy sets has several advantages. First, the technique enables the identification of any potential patterns in both necessary and sufficient causal conditions that promote higher GDP growth rates. This, in turn, will help to establish the extent to which institutional regimes are likely to converge across the region to a common model that includes regulations that lower the transaction costs of doing business. Second, fuzzy sets are particularly appropriate for research designs that are limited to a relatively small number of observations, which is often the case with cross-country analyses (Jackson, 2005). Finally, fuzzy sets facilitate a more nuanced examination of "causal complexity" to put it one way (Ragin, 2008a) or "institutional complementarities" as others have put it (Hall and Soskice, 2001; Whitley, 2007).

Building on the arguments presented above, it is necessary to include issues of corporate governance into the analysis. Within the comparative-capitalisms literature, the issue of corporate governance, broadly defined, is a central one; it has been ascribed an important role in capitalism in CEE (Bohle and Greskovits, 2006; Hall and Soskice, 2001; Nölke and Vliegenthart, 2009; Whitley, 2007). As a result of the large amount of foreign investment in CEE and as a result of formerly state-owned enterprises being privatized and then taken over by overseas companies, there have been important changes to the corporate-governance systems of enterprises in the region, as many CEE firms are now controlled by others outside the region (Lane, 2007; Nölke and Vliegenthart, 2009).

The influence of those based outside the region does not stop there: the corporate-governance codes of the region have been strongly shaped by transnational entities (Nölke and Vliegenthart, 2009), banks in CEE are often foreign owned (Bohle and Greskovits, 2006), and overseas investors own a large proportion of equities that are listed on the region's stock markets (Allen and Aldred, 2009). If foreign investors wish to have a more direct influence over CEE companies, they will own outright their overseas subsidiaries. This, in turn, will mean that they are not listed on local stock markets and, hence, will not have to adhere to the relevant host-country regulations. Consequently, host-country stock markets will be of little relevance to them (Lane, 2007; Myant, 2007). Additionally, wholly owned subsidiaries may be less likely to be reliant on banks in the region for funding. If FDI is, indeed, the preferred route for foreign companies to co-ordinate and control their subsidiaries in CEE, then those countries that attract the most FDI can be expected to be the ones to post the strongest 
GDP growth rates. In addition, if FDI is one of the main routes to higher economic growth levels, as the orthodox international literature would expect, then domestic banks and stock markets are likely to contribute less to increases in GDP rates in the New EU member region. The figures on FDI, stock market capitalization, and domestic lending will help to identify the most important sources of growth as being foreign, domestic, or both.

Another key element within the comparative-capitalisms literature is the employment system, which covers various forms of employment regulations, such states as employment protection, wage bargaining and workplace representation. This is an area where there is a clear distinction between the two perspectives covered here, as the analytical focus is narrower in the international-business literature than it is within the comparative-capitalisms approach. Much of the transaction cost-inspired international-business literature would see employment regulations as a burden for firms (Djankov et al., 2006), whilst the comparative-capitalisms approach contends that, under certain conditions, they can be beneficial to firms (Harcourt and Wood, 2007; Whitley, 2007).

As noted above, regulations surrounding market-based activities are deemed to be of great significance in many analyses within the international-business literature in assessments of firms' overseas expansion, as they can alter transaction costs (Meyer, 2001; Meyer and Peng, 2005). This may deter overseas companies from investing. Indeed, overseas companies may not invest even if they view employment regulations favourably. The mainstream international-business literature would also view regulations that place a burden on domestic firms as deleterious to growth. The inclusion of a variable that measures the ease of doing business in a country is an appropriate way to capture these more general aspects of a country's business environment.

Another factor that is likely to increase GDP growth rates is the availability of well-educated employees. In order to capture this possibility, this research includes the percentage of the labour force that has successfully completed a tertiary-level qualification. Tertiary education covers university undergraduate degrees. Whilst this measure cannot capture the quality of those graduates, no comparable data exist that cover such finely grained details. Moreover, the inclusion of the variable that is used here is in line with related studies (Schneider et al., 2010). It will also help to shed light on the extent to which states in CEE, if they wish to grow, will have to promote not only the establishment of markets, but also increase workforce skills, by, for instance, increasing the numbers of those going to university.

The new EU member states in CEE provide a strong basis upon which to assess the possibility that, for countries to grow economically, they need to conform to high standards in terms of the legal basis for, and enforcement of, market-based contracting. Indeed, they offer prime cases to study the extent to which these systems are likely to converge around a common model. As noted above, the new member states are highly dependent upon inward FDI (Bohle and Greskovits, 2006; Lane and Myant, 2007; Nölke and Vliegenthart, 2009), have experienced strong pressures to create regulatory environments that are attractive to outside investors (Hansmann and Kraakman, 2001; Lane, 2007; McCahery et al., 2004), and have been through a period when constraints on institutional change were relatively limited (Vaughan-Whitehead, 2003). 


\section{CPOIB}

9,3

308

\section{Data, method, and variable calibration}

In order to assess the extent to which the desire to increase GDP growth rates is likely to create pressures for economies in CEE to converge around a model that privileges strong regulations that facilitate market-based transactions, all ten countries from CEE that joined the EU in either 2004 or 2007 have been included in the analysis. In order to ensure that the results are not biased by, for instance, large one-off investments by foreign firms, mean annual values for the five-year period (2005 until 2009, inclusive) have been used for most of the variables in this study. The year 2009 is the latest for which most measures are available. The data on employment and business regulations are only available for one year; these values do not, however, suffer from large annual variations.

Data for this factor along with those for six of the causal conditions were collected from the World Bank's World Development Indicators dataset, which itself draws on a number of sources. More recent editions of the World Bank's Doing Business report as well as the related World Economic Forum's Global Competitiveness analyses do not provide information on employment and business regulation in the same form as earlier editions; this prevents overall assessments of the transaction cost-reducing effects of employment and business regulations being made. No other sources of information cover these key variables for the whole CEE region. Data on "employee participation" are from the European Trade Union Institute (ETUI). These data are for 2006; once again, this measure is not subject to significant fluctuations. The "raw data" for all of the variables used in this analysis are shown in Table I; the sources and definitions for that data are set out in Table II.

The outcome variable is GDP growth rates. A number of measures that can lead to economic growth, in general, as well as those that relate to particular institutions that have been highlighted within the comparative-capitalisms and international-business literatures have been included in the analysis. Those general factors include FDI as this is especially important for the economic transition that has taken place in CEE. This is captured by net FDI inflows as a percentage of GDP. Domestic lending and stock markets can also help firms to grow. Therefore, this article also includes levels of domestic credit (primarily, lending by banks in one country to companies in the same country as a percentage of GDP) as well as domestic stock market capitalization (the market capitalization of indigenous companies as a percentage of GDP).

In order to capture institutions that are pertinent to both the mainstream international-business and comparative-capitalisms literatures, this paper includes an "employment rigidity" index which captures general employment legislation, as well as the European Participation Index, which measures workplace and board-level employee representation, collective bargaining coverage rates, and trade union density. The former literature would expect high values on both indices to impede market-based transacting and, consequently, to lower economic growth. The latter literature would be more circumspect and would acknowledge that such institutions can have a beneficial impact on firms. The general regulatory environment is captured by the ease of doing business index - expressed in the analysis as the rigidity of doing business in order to aid the interpretation of the results. The ease with which legal agreements between corporations can be up-held in the courts is measured by the ability to enforce contracts. Once again, if contentions within the mainstream international-business literature are correct, high values on these final two measures 


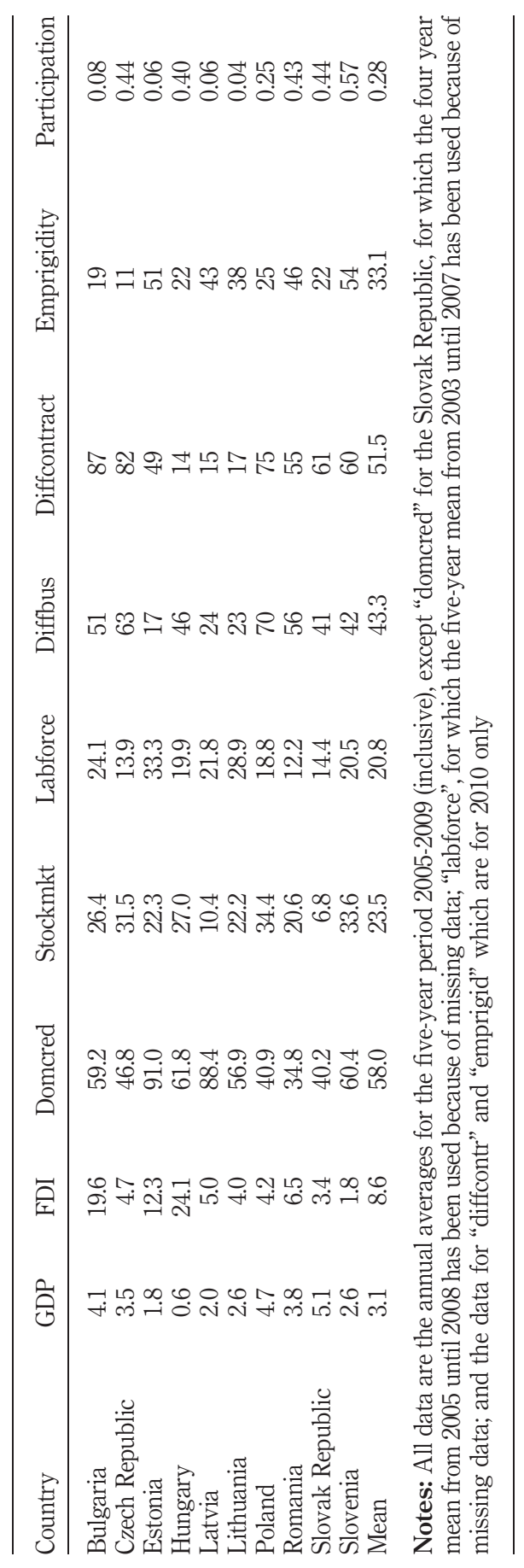

New EU member states

309

Table I.

Data used in the analysis prior to transformation 
CPOIB

9,3

310

Table II.

Causal conditions:

definitions and sources

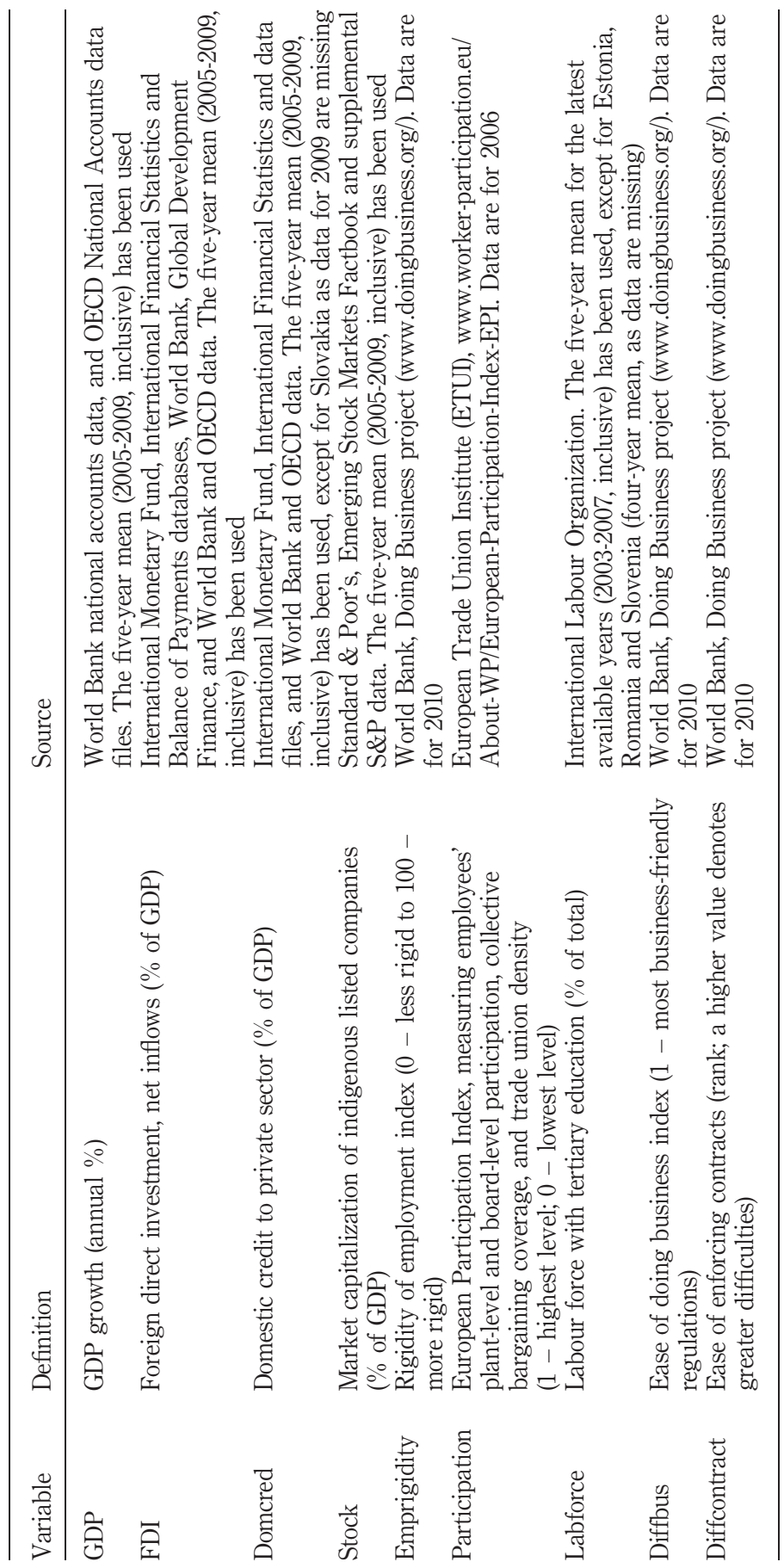


can be expected to be associated with lower economic growth rates. This is because market-based transactions will be impaired. By contrast, the comparative-capitalisms literature would more readily accept that firms may be able to develop competitive competencies despite such institutional constraints.

Developed by Ragin (2000, 2006, 2008a) and drawing on Boolean algebra, fsQCA provides a means to assess the relationship between combinations of "causal conditions" and the outcome in question. In short, fsQCA examines how the membership of cases in the set of causal conditions is linked to membership in the outcome set. One advantage of using fsQCA here is that it enables potential clusters of institutional configurations and, hence, countries to be identified. If any such clusters are found, this would, potentially, reveal strong convergence tendencies amongst countries in the region. If, on the other hand, there are no clusters of either necessary or sufficient causal conditions, such tendencies will be less. An additional advantage of the fsQCA approach is that it allows for the possibility that more than one combination of causal conditions may be found to be linked to the same outcome. In other words, there may be more than one way for countries to achieve high GDP growth rates. Finally, fsQCA can examine the links between various combinations of causal conditions and the outcome as both necessary and sufficient conditions. This is important here, as it is yet to be established whether certain institutional features are either necessary and/or sufficient for countries in CEE to achieve strong GDP growth rates. This may, in turn, lead to clearer policy implications than would be the case from an analysis of the marginal effects obtained from regression analyses (Schneider et al., 2010).

In order to use the data as part of a fuzzy-set analysis, the figures had to be transformed or calibrated. Using calibrated rather than uncalibrated data means that the information used in the analysis is based on finely grained measurements of the degree of membership of cases in sets (Ragin, 2008b, pp. 16-17). Thus, the use of fuzzy sets that can take scores ranging from 0.0 to 1.0 leads to a more nuanced approach to the data being adopted than would be the case if, say, a five- or six-point set had been used.

To establish the set membership values, three anchor points need to be determined: two extreme points defining full membership and full non-membership, and a cross-over point at which the country is neither in nor out of the set (Ragin, 2000, pp. 158-159). These anchors, which are needed for calibrating sets using the "direct method", are assigned set membership values of 1,0 , and 0.5 , respectively. The "direct method" of calibrating set membership relies on specifying the numerical values linked to the three qualitative anchors (full membership, full non-membership, and the cross-over point). (The "indirect method" relies on the researcher's judgement to group cases according to their membership in the target set (Ragin, 2008a, p. 16). A value of 1 was assigned to the country with the highest annualized GDP growth rate between 2005 and 2009 (inclusive) (Slovak Republic with 5.1 per cent); 0 to the country with the lowest (Hungary 0.6 per cent). The cross-over point was calculated as the arithmetic mean for all of the countries (3.1 per cent). Given these three anchor points, the set membership values for all cases were calculated by using the log odds method described by Ragin (2008a). Using this measure, five countries are members of the "high GDP growth rate" set (Bulgaria, the Czech Republic, Poland, Romania, and the Slovak Republic). The same procedure that was used to calculate the set membership

\section{New EU member states}

311 
CPOIB 9,3

\section{2}

Table III.

Analysis of necessary conditions for high GDP growth rates was used for all of the causal conditions. In other words, for each variable, full membership of a set was based on the highest value in that set; full non-membership on the lowest value; and the cross-over point on the arithmetic mean. This results in countries having varying membership for each institutional variable.

\section{Results \\ Necessary conditions and functional equivalents}

The analysis begins by examining whether any of the causal conditions can be considered "necessary" for the outcome. A necessary causal condition is one for which the instances of the outcome constitute a subset of the instances of the causal condition (Ragin, 2006, p. 297). In other words, a necessary cause, as Ragin (2000, p. 91) has noted, is one that "must be present for the outcome in question to occur". Its presence does not, however, "automatically" lead to the outcome. This means that, for each case, the values of the set membership for the outcome will be lower than the values for the set membership for the necessary cause. However, as the data do not, normally, conform to that specification, fsQCA draws on consistency measures, which are calculated using probabilities, to enable assessments of the degree to which observations meet the requirement of necessity. Following the consistency rule suggested by Ragin (2006, pp. 296-297), the analysis views near misses favourably, but sees those cases in which the scores for the causal membership greatly exceed those for the outcome membership negatively.

A consistency score of 1 denotes that the causal condition or combination of causal conditions meets the necessity rule across all cases. Values closer to 0 indicate either that many cases fail to conform to that rule and/or that there are a large proportion of cases that are a long way from meeting that rule. If a causal condition or a combination of them has a consistency score of 0.9 or above, this is, conventionally, deemed to be a "necessary" or "almost always necessary" condition. Table III shows the results of the

\begin{tabular}{lcc}
\hline Condition tested & Consistency & Coverage \\
\hline domcred & 0.878 & 0.801 \\
DIFFCONTRACT & 0.856 & 0.780 \\
DIFFBUS & 0.796 & 0.783 \\
fdi & 0.774 & 0.586 \\
labforce & 0.749 & 0.702 \\
emprigidity & 0.741 & 0.760 \\
STOCKMKT & 0.660 & 0.582 \\
PARTICIPATION & 0.622 & 0.616 \\
stockmkt & 0.434 & 0.535 \\
participation & 0.402 & 0.430 \\
LABFORCE & 0.325 & 0.369 \\
EMPRIGIDITY & 0.322 & 0.331 \\
diffbus & 0.282 & 0.304 \\
FDI & 0.281 & 0.449 \\
DOMCRED & 0.235 & 0.276 \\
diffcontract & 0.224 & 0.264
\end{tabular}

Notes: Outcome variable is GDP; the use of upper case denotes the presence of a condition, and lower case, its absence 
analysis of causal conditions for all eight of the factors included here. Following New EU member convention, conditions that are written in lower case denote "non-membership" of that set; those in upper case represent membership. None of causal condition exceeds the states threshold of 0.9. In other words, not one of the causal conditions countries examined here creates the necessary conditions for high GDP growth rates. This, as is discussed below, is an important finding, as it suggests that there is no single factor that countries in the region can change in order to promote higher GDP growth rates.

\section{Sufficient conditions}

The analysis of sufficient conditions is based on the set-theoretic reasoning that a sufficient cause is one that, in a strict interpretation, leads to the outcome if, for all cases, the fuzzy-set membership value of the causal condition does not exceed the fuzzy membership value of the outcome (Ragin, 2006). Combinations of factors can be considered in the same way and are denoted by a logical "AND" (*). As individual cases or combinations of them are unlikely to satisfy the strict criterion for sufficiency across all cases, a consistency measure, as specified in Ragin (2006), is needed.

Those causal combinations that exceed a certain consistency score are categorized as sufficient. This leads to such cases being assigned a value of 1 in the truth table for the outcome (GDP). Those causal combinations that have a consistency score below the cut-off point are not deemed to be sufficient, and they receive a score of 0 for the outcome. Using 0.80 as the cut-off point for sufficiency leads to the combinations of causal conditions and outcome shown in Table IV. Out of the 258 possible logical combinations of causal factors, 10 are observed. The fact that there are not fewer observed combinations suggests that there is little complementarity between the various institutions. In other words, having higher levels of, for instance, stock market capitalization does not mean that, say, employee-participation levels will be comparatively strong or weak. This evidence indicates that there has been little convergence around any particular institutional model or models amongst the new EU member states in CEE.

In order to examine the sufficiency of the causes for strong GDP growth rates, a truth-table algorithm is applied. The "intermediate" solution is shown, which is recommended by Ragin (2008a, pp. 160-175) for interpretation. Each line in Table V represents a combination of sufficient conditions that lead to the outcome. As can be seen, all sufficient causes consist of more than one condition. In short, there is no one condition that is, by itself, sufficient to account for high GDP growth rates.

Four ways to achieve high GDP growth rates emerge from the sufficiency analysis. The scores for "raw coverage" and "unique coverage" that are shown in the Table help to assess the empirical importance of these four routes to success in advanced technology markets (Ragin, 2006). Raw coverage refers to the extent of the overlap between the causal combination set and the outcome set relative to the size of the outcome set (Ragin, 2006, p. 301). The measure for unique coverage controls for overlapping explanations by drawing on the raw coverage data. For any particular causal combinations, it is calculated by subtracting the raw-coverage score for all the other causal combinations (i.e. excluding the one of interest) from the raw-coverage score for all the causal combinations (including the one of interest). As there are four causal combinations that explain strong GDP growth rates, the unique coverage score 
CPOIB

9,3

\section{4}

Table IV.

Truth table and assignment of countries to institutional configurations (logical remainders not listed)

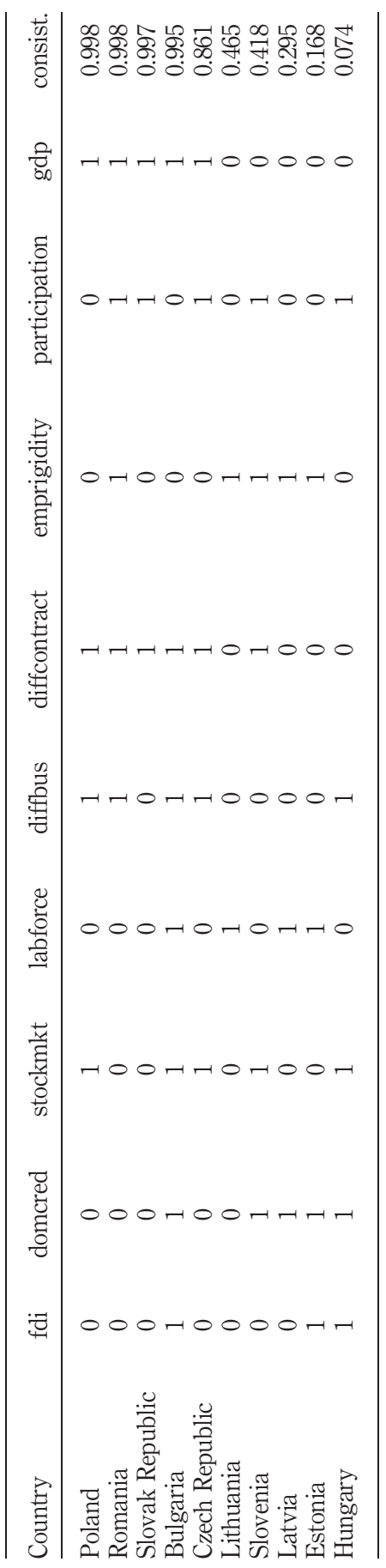




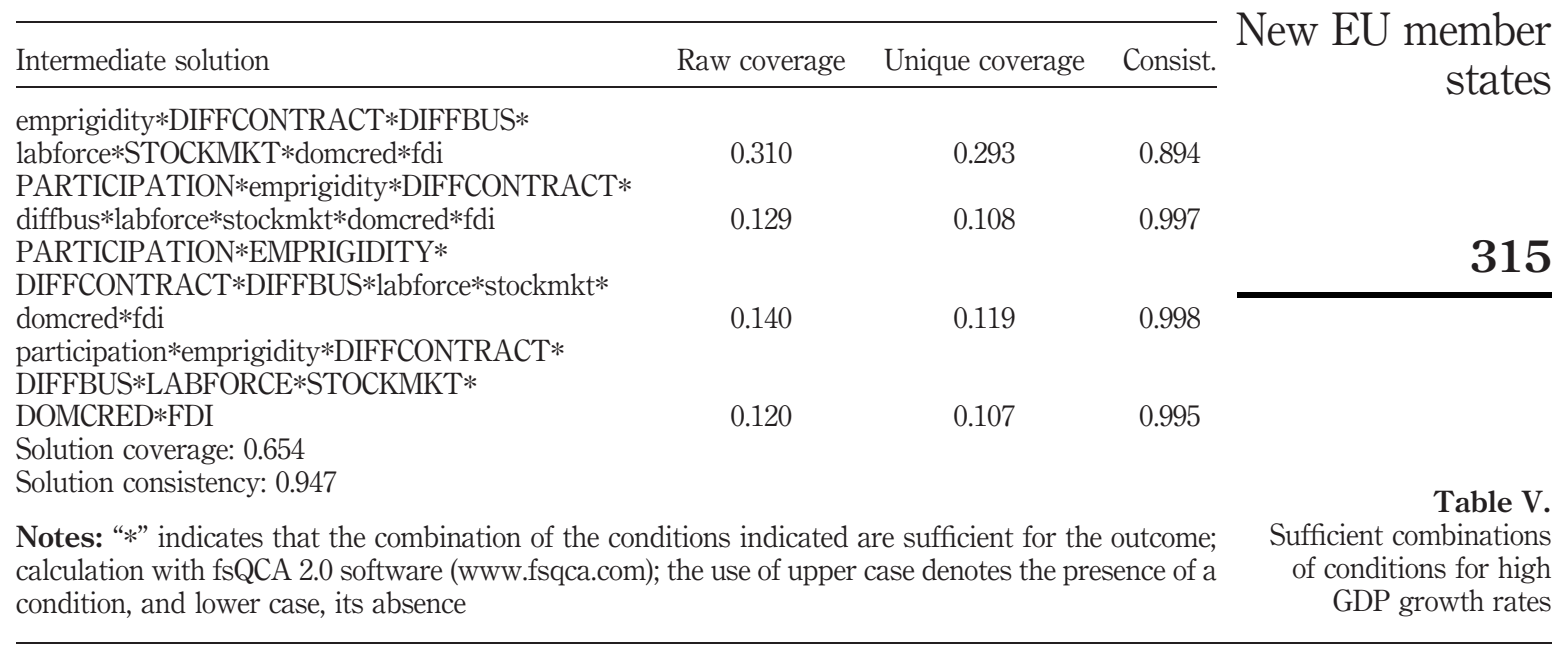

for each combination is relatively modest. This indicates a relatively high degree of diversity amongst those CEE countries that have strong economic growth records.

The four sufficient combinations of conditions have one factor in common. That factor is, from a comparative-capitalisms and, a fortiori, from an international-business perspective somewhat surprisingly, the difficulty in enforcing contracts. In other words, the more onerous it is to ensure compliance with the terms and conditions of a legal agreement between two companies, the higher the GDP growth rate is likely to be. In addition, the general difficulty in doing business in a country is, in three of the four combinations, a factor that helps to explain higher GDP growth rates. This does not conform to expectations within the international-business literature. The finding that, in three of the four combinations of conditions, more de-regulated employment standards promote higher levels of economic growth is more in line with the expectations of the international-business literature (Djankov et al., 2006).

The lack of consistency in the combinations of sufficient causes is at odds with some of the arguments within the comparative-capitalisms perspective: if institutions do complement one another, this will reduce the number of combinations of causal conditions that explain higher GDP growth rates (Hall and Gingerich, 2009). However, the fact that a wide range of causal conditions are needed to explain stronger economic growth rates is more in keeping with the expectations of the comparative-capitalisms literature than those of the international-business literature. This is because greater emphasis is attached to the creation and development of organizational capabilities and, hence, the ways in which these are institutionally structured in the former perspective compared to the latter.

\section{Discussion and implications for future research}

The findings here suggest that "institutional voids" and other aspects of institutions that hinder market-based transacting do not necessarily impede economic growth. Indeed, somewhat unexpectedly, firms' inability to enforce contracts as well as the general difficulties that firms face in doing business in a particular country would appear to be associated with higher economic growth rates in CEE over the period 
CPOIB

9,3

316 covered. Whilst it would be inappropriate to base firm conclusions on the evidence from one study, the results do suggest that analyses that focus primarily on the transaction cost-reducing effect of institutions do not capture the complete picture. For instance, the pressures for convergence are not as great as some have argued (Djankov et al., 2006; Meyer et al., 2011; Globerman and Shapiro, 2003): some of the countries that have institutions, such as general difficulties in doing business, problems enforcing contracts, and high levels of employee participation in firm decision making, that impede market transactions (Bulgaria, Poland, Romania, and the Slovak Republic) perform better than those that have more market-supporting ones, such as Estonia and Latvia, during the analysed period. This indicates that firms can overcome these institutional constraints in ways not foreseen by much international-business research.

To be sure, some international-business research has focused on the ways in which firms may overcome "market deficiencies" or "institutional voids" to become competitive (Miller et al., 2009; Puffer et al., 2010); however, the analytical focus remains on personal ties that enable companies to perform activities that can be expected to be carried out elsewhere by the market. Although, very little research within the comparative-capitalisms literature has focused on the ways in which firms in "fragmented business systems" (Whitley, 1999) may or may not become competitive (Wood and Frynas, 2006), that strand of the literature broadens the analytical focus beyond transaction costs and adopts a richer approach to institutions (Jackson and Deeg, 2008). This extends to the consideration of how the benefits of economic growth are distributed and, hence, how institutional differences may persist (Wood and Frynas, 2006).

For instance, the comparative-capitalisms literature stresses the importance of examining a number of institutions and the ways in which they interact with one another, as shortcomings in one institutional domain may be counteracted by strengths in another. Thus, institutions can complement one another in the form of making up for deficiencies (Crouch, 2005, p. 50). However, the particular ways in which institutions can counteract the effects of one another have not been examined in detail in the comparative-capitalisms literature. The results here suggest that complementary and countervailing influences of institutions on firm behaviour are likely to be highly complex. They show that the presence of one particular institution does not hinder economic growth. Similarly, there is no one institution that, when present, is consistently associated with higher levels of economic growth. Although the values for the "difficulties enforcing contracts" is above average for all of the countries that have stronger GDP growth rates (Bulgaria, Czech Republic, Poland, Romania, and Slovak Republic) there is considerable variation along the other variables included in this study that account for higher GDP growth rates. In short, there would appear to be little institutional coherence amongst the new EU member states in CEE.

In addition, the above analysis reveals that institutions that raise transaction costs in one area, such as the difficulty of doing business in any one country, are not necessarily associated with institutions that increase them in other domains, such as enforcing a contract and vice versa. This suggests that a typology of countries could be developed that differentiates between the particular types of transactions cost-increasing (and other) institutions in different countries. Once again, the more nuanced view of institutions within the comparative-capitalisms literature provides a foundation for doing this (Jackson and Deeg, 2008; Wood and Frynas, 2006). This 
would enable an analysis of the ways in which particular institutions both individually and collectively impact upon firms. Such a typology would need to take into consideration the highly complex way in which institutional complementarity operates the region. In short, there is a great deal of institutional diversity within the new EU member states in CEE. There are no clusters of countries around a specific variety of capitalism or an economic model that, in order to grow, must adopt certain characteristics that promote market-based transactions.

Such a typology could build on existing work within the comparative-capitalisms literature that tends to incorporate interactions between institutions into its analysis. By contrast, the mainstream international-business literature tends to look at institutions individually. So, for instance, in that literature, labour-market institutions that do not enable managers in firms to determine employment practices that they deem to be most appropriate will hinder growth (Djankov et al., 2006; Khanna and Palepu, 2010). In the comparative-capitalisms Maria L. Aldredliterature, institutions may not just reduce the flow of information or act as constraints on managerial decision making, but may enable companies to develop organizational capabilities that, in the institutions' absence, would be difficult to achieve (Harcourt and Wood, 2007; Whitley, 2007). Enabling employees to participate in company decision making may help to increase GDP growth rates, as the examples of the Czech Republic, Romania, and the Slovak Republic illustrate. Thus, too narrow a focus on transaction costs may lead to important aspects of firms' development being downplayed.

Indeed, the differences between the empirically important causal combinations of factors that are sufficient to explain stronger GDP growth rates suggest that institutional convergence around a transaction cost-reducing institutional framework will not occur in CEE. For instance, one of the differences between Bulgaria and Hungary is that contracts are appreciably more difficult to enforce in Bulgaria than they are in Hungary; yet the former country has a superior record on economic growth during the period covered than the latter. Hence, the specific institutional contexts of firms matters greatly. By analysing outcomes across an important and dynamic region, it is hoped that this research has provided the basis for that assessment to be undertaken.

\section{References}

Allen, M.M.C. and Aldred, M.L. (2009), "Varieties of capitalism, varieties of innovation? A comparison of old and new EU member states", Journal of Contemporary European Research, Vol. 5 No. 4, pp. 581-596.

Allen, M.M.C. and Aldred, M.L. (2011), "Varieties of capitalism, governance, and high-tech export performance: a fuzzy-set analysis of the new EU member states", Employee Relations, Vol. 33 No. 4, pp. 334-355.

Allen, M.M.C., Funk, L. and Tüselmann, H.-J. (2006), “Can variation in public policies account for differences in comparative advantage?”, Journal of Public Policy, Vol. 26 No. 1, pp. 1-19.

Allen, M.M.C., Tüselmann, H.-J. and Aldred, M.L. (2011), "Institutional frameworks and radical innovation: an analysis of high- and medium-high-technology industries in Germany", International Journal of Public Policy, Vol. 7 Nos 4-6, pp. 265-281.

Allen, M.M.C., Tüselmann, H.-J., El-Sa'id, H. and Windrum, P. (2007), "Sectoral collective agreements: remuneration straitjackets for German workplaces?”, Personnel Review, Vol. 36 No. 6, pp. 963-977.

\section{New EU member} states

317 
CPOIB

9,3

318

Becker-Ritterspach, F., Saka-Helmhout, A. and Hotho, J.J. (2010), "Learning in multinational enterprises as the socially embedded translation of practices", Critical Perspectives on International Business, Vol. 6 No. 1, pp. 8-37.

Bevan, A., Estrin, S. and Meyer, K.E. (2004), "Foreign investment location and institutional development in transition economies", International Business Review, Vol. 13 No. 1, pp. 43-64.

Bohle, D. and Greskovits, B. (2006), "Capitalism without compromise: strong business and weak labor in Eastern Europe's new transnational industries", Studies in Comparative International Development, Vol. 41 No. 1, pp. 3-25.

Botero, J., Djankov, S., La Porta, R., Lopez-de-Silanes, S. and Shleifer, A. (2004), “The regulation of labor", The Quarterly Journal of Economics, Vol. 119 No. 4, pp. 1339-1382.

Boyer, R. (2004), "New growth regimes, but still institutional diversity", Socio-Economic Review, Vol. 2 No. 1, pp. 1-32.

Boyer, R. (2011), “Are there laws of motion of capitalism?”, Socio-Economic Review, Vol. 9 No. 1, pp. 59-81.

Brouthers, K.D. (2002), "Institutional, cultural and transaction cost influences on entry mode choice and performance", Journal of International Business Studies, Vol. 33 No. 2, pp. 203-221.

Casper, S. and Whitley, R. (2004), "Managing competences in entrepreneurial technology firms: a comparative institutional analysis of Germany, Sweden, and the UK", Research Policy, Vol. 33 No. 1, pp. 89-106.

Chakrabarty, S. (2009), "The influence of national culture and institutional voids on family ownership of large firms: a country level empirical study", Journal of International Management, Vol. 15 No. 1, pp. 32-45.

Crouch, C. (2005), Capitalist Diversity and Change: Recombinant Governance and Institutional Entrepreneurs, Oxford University Press, Oxford.

Crouch, C., Streeck, W., Boyer, R., Amable, B., Hall, P.A. and Jackson, G. (2005), "Dialogue on institutional complementarity and political economy", Socio-Economic Review, Vol. 3 No. 2, pp. 359-382.

Cuervo-Cazurra, A. and Genc, M. (2008), "Transforming disadvantages into advantages: developing-country MNEs in the least developed countries", Journal of International Business Studies, Vol. 39 No. 6, pp. 957-979.

Delios, A. and Henisz, W.J. (2003), "Policy uncertainty and the sequence of entry by Japanese firms, 1980-1998", Journal of International Business Studies, Vol. 34 No. 3, pp. 227-241.

Djankov, S., McLiesh, C. and Ramalho, R.M. (2006), "Regulation and growth”, Economics Letters, Vol. 92 No. 3, pp. 395-401.

Dunning, J.H. (2009), "Location and the multinational enterprise", Journal of International Business Studies, Vol. 40 No. 1, pp. 20-34.

Estrin, S. and Prevezer, M. (2011), "The role of informal institutions in corporate governance: Brazil, Russia, India and China compared", Asia Pacific Journal of Management, Vol. 28 No. 1, pp. 41-67.

Globerman, S. and Shapiro, D. (2003), "Governance infrastructure and foreign direct investment", Journal of International Business Studies, Vol. 34 No. 1, pp. 19-39.

Hall, P.A. and Gingerich, D.W. (2009), "Varieties of capitalism and institutional complementarities in the political economy: an empirical analysis", British Journal of Political Science, Vol. 39 No. 3, pp. 449-482. 
Hall, P.A. and Soskice, D. (2001), "Introduction", in Hall, P.A. and Soskice, D. (Eds), Varieties of Capitalism: The Institutional Foundations of Comparative Advantage, Oxford University Press, Oxford, pp. 1-68.

Hansmann, H. and Kraakman, R. (2001), "The end of history for corporate law", Georgetown Law Journal, Vol. 89 No. 2, pp. 439-468.

Harcourt, M. and Wood, G. (2007), "The importance of employment protection for skill development in coordinated market economies", European Journal of Industrial Relations, Vol. 13 No. 2, pp. 141-159.

Henisz, W.J. (2000), "The institutional environment for economic growth", Economics and Politics, Vol. 12 No. 1, pp. 1-31.

Hotho, J.J. and Pedersen, T. (2012), "Beyond the 'rules of the game': three institutional approaches and how they matter for international business", in Wood, G. and Demirbag, M. (Eds), Handbook of Institutional Approaches to International Business, Edward Elgar, Cheltenham, pp. 236-273.

Jackson, G. (2005), "Employee representation in the board compared: a fuzzy sets analysis of corporate governance, unionism and political institutions", Industrielle Beziehungen, Vol. 12 No. 3, pp. 252-279.

Jackson, G. and Deeg, R. (2008), "Comparing capitalisms: understanding institutional diversity and its implications for international business", Journal of International Business Studies, Vol. 39 No. 4, pp. 540-561.

Khanna, T. and Palepu, K.G. (1997), "Why focused strategies may be wrong for emerging markets”, Harvard Business Review, Vol. 75 No. 4, pp. 41-51.

Khanna, T. and Palepu, K. (1999), "The right way to structure conglomerates in emerging markets", Harvard Business Review, Vol. 77 No. 4, pp. 125-134.

Khanna, T. and Palepu, K. (2000), "Is group affiliation profitable in emerging markets? An analysis of diversified Indian business groups", Journal of Finance, Vol. 55 No. 4, pp. 867-891.

Khanna, T. and Palepu, K.G. (2004), "Globalization and convergence in corporate governance: evidence from Infosys and the Indian software industry", Journal of International Business Studies, Vol. 35 No. 6, pp. 484-507.

Khanna, T. and Palepu, K.G. (2006), "Emerging giants: building world-class companies in developing countries", Harvard Business Review, Vol. 84 No. 10, pp. 60-69.

Khanna, T. and Palepu, K.G. (2010), Winning in Emerging Markets: A Road Map for Strategy and Execution, Harvard Business Press, Cambridge, MA.

Khanna, T. and Rivkin, J.W. (2001), "Estimating the performance effects of business groups in emerging markets", Strategic Management Journal, Vol. 22 No. 1, pp. 45-74.

Lane, D. (2007), "Post-state socialism: a diversity of capitalisms?", in Lane, D. and Myant, M. (Eds), Varieties of Capitalism in Post-Communist Countries, Palgrave Macmillan, London, pp. 13-39.

Lane, D. and Myant, M. (Eds) (2007), Varieties of Capitalism in Post-Communist Countries, Palgrave Macmillan, London.

McCahery, J.A., Renneboog, L., Ritter, P. and Haller, S. (2004), "The economics of the proposed European takeover directive", in Ferrarini, G., Hopt, K.J., Winter, J. and Wymeersch, E. (Eds), Reforming Company and Takeover Law in Europe, Oxford University Press, Oxford, pp. 575-646.

Meyer, K.E. (2001), "Institutions, transaction costs, and entry mode choice in Eastern Europe", Journal of International Business Studies, Vol. 32 No. 2, pp. 357-367. 


\section{CPOIB}

9,3

320
Meyer, K.E. and Peng, M.W. (2005), "Probing theoretically into Central and Eastern Europe, transactions, resources, and institutions", Journal of International Business Studies, Vol. 36 No. 6, pp. 600-621.

Meyer, K.E., Mudambi, R. and Narula, R. (2011), "Multinational enterprises and local contexts: the opportunities and challenges of multiple embeddedness", Journal of Management Studies, Vol. 48 No. 2, pp. 235-252.

Miller, D., Lee, J., Chang, S. and Le Breton-Miller, I. (2009), "Filling the institutional void: the social behavior and performance of family vs non-family technology firms in emerging markets", Journal of International Business Studies, Vol. 40 No. 5, pp. 802-817.

Miozzo, M. and Yamin, M. (2012), "Institutional and sectoral determinants of headquarters-subsidiary relationships: a study of UK service multinationals in China, Korea, Brazil and Argentina”, Long Range Planning, Vol. 45 No. 1, pp. 16-40.

Mudambi, R. and Navarra, P. (2002), "Institutions and international business: a theoretical overview”, International Business Review, Vol. 11 No. 6, pp. 635-646.

Myant, M. (2007), “The Czech Republic: from ‘Czech’ capitalism to 'European’ capitalism”, in Lane, D. and Myant, M. (Eds), Varieties of Capitalism in Post-Communist Countries, Palgrave Macmillan, London, pp. 105-123.

Nölke, A. and Vliegenthart, A. (2009), "Enlarging the varieties of capitalism: the emergence of dependent market economies in east central Europe", World Politics, Vol. 61 No. 4, pp. 670-702.

Pajunen, K. (2008), "Institutions and inflows of foreign direct investment: a fuzzy-set analysis", Journal of International Business Studies, Vol. 39 No. 4, pp. 652-669.

Peng, M.W., Lee, S.-H. and Wang, D.Y.L. (2005), "What determines the scope of the firm over time? A focus on institutional relatedness", Academy of Management Review, Vol. 30 No. 3, pp. 622-633.

Peng, M.W., Wang, D. and Jiang, Y. (2008), “An institution-based view of international business strategy: a focus on emerging economies”, Journal of International Business Studies, Vol. 39 No. 5, pp. 920-936.

Puffer, S.M., McCarthy, D.J. and Boisot, M. (2010), "Entrepreneurship in Russia and China: the impact of formal institutional voids", Entrepreneurship Theory and Practice, Vol. 34 No. 3, pp. 441-467.

Ragin, C.C. (2000), Fuzzy-Set Social Science, Chicago University Press, Chicago, IL.

Ragin, C.C. (2006), "Set relations in social research: evaluating their consistency and coverage", Political Analysis, Vol. 14 No. 3, pp. 291-310.

Ragin, C.C. (2008a), Redesigning Social Inquiry: Fuzzy Sets and Beyond, University of Chicago Press, Chicago, IL.

Ragin, C.C. (2008b), User's Guide to Fuzzy-Set/Qualitative Comparative Analysis, available at: www.u.arizona.edu/ cragin/fsQCA/download/fsQCAManual.pdf

Rugman, A., Verbeke, A. and Yuan, W. (2011), "Re-conceptualizing Bartlett and Ghoshal's classification of national subsidiary roles in the multinational enterprise", Journal of Management Studies, Vol. 48 No. 2, pp. 253-277.

Schneider, M.R., Schulze-Bentrop, C. and Paunescu, M. (2010), "Mapping the institutional capital of high-tech firms: a fuzzy-set analysis of capitalist variety and export performance", Journal of International Business Studies, Vol. 41 No. 2, pp. 246-266.

Streeck, W. (1997), "Beneficial constraints: on the economic limits of rational voluntarism", in Hollingsworth, J.R. and Boyer, R. (Eds), Contemporary Capitalism: The Embeddedness of Institutions, Cambridge University Press, Cambridge, pp. 197-219. 
Tan, D. and Meyer, K.E. (2010), “Business groups' outward FDI: a managerial resources perspective”, Journal of International Management, Vol. 16 No. 2, pp. 154-164.

Vaughan-Whitehead, D. (2003), EU Enlargement Versus Social Europe? The Uncertain Future of the European Social Model, Edward Elgar, Cheltenham.

Whitley, R. (1999), Divergent Capitalisms: The Social Structuring and Change of Business Systems, Oxford University Press, Oxford.

Whitley, R. (2006), "Understanding differences: searching for the social processes that construct and reproduce variety in science and economic organization”, Organization Studies, Vol. 27 No. 8, pp. 1153-1177.

Whitley, R. (2007), Business Systems and Organizational Capabilities: The Institutional Structuring of Competitive Competences, Oxford University Press, Oxford.

Whitley, R. and Morgan, G. (2012), "Introduction", in Morgan, G. and Whitley, R. (Eds), Capitalisms and Capitalism in the Twenty-First Century, Oxford University Press, Oxford, pp. 1-10.

Wood, G. and Frynas, G. (2006), "The institutional basis of economic failure: anatomy of the segmented business system”, Socio-Economic Review, Vol. 4 No. 2, pp. 239-277.

Wood, G. and Lane, C. (2012), "Institutions, change, and diversity", in Lane, C. and Wood, G.T. (Eds), Capitalist Diversity and Diversity within Capitalism, Routledge, London, pp. 1-31.

Young, M.N., Peng, M.W., Ahlstrom, D., Bruton, G.D. and Jiang, Y. (2008), “Corporate governance in emerging economies: a review of the principal-principal perspective", Journal of Management Studies, Vol. 45 No. 1, pp. 196-220.

\section{Further reading}

Allen, M.M.C. (2004), “The varieties of capitalism paradigm: not enough variety?", Socio-Economic Review, Vol. 2 No. 1, pp. 87-107.

\footnotetext{
About the authors

Matthew M.C. Allen is a Senior Lecturer in Organization Studies at Manchester Business School, The University of Manchester. Matthew M.C. Allen is the corresponding author and can be contacted at: matthew.allen@mbs.ac.uk

Maria L. Aldred is a Senior Lecturer in International Business at Manchester Metropolitan University Business School.
} 